\title{
Beyond Modern Money Theory: a Post-Keynesian approach to the currency hierarchy, monetary sovereignty, and policy space
}

\author{
Daniela Prates* \\ Senior Economic Affairs Officer, United Nations Conference on Trade and Development (UNCTAD) and \\ Associate Professor of Economics (on leave), University of Campinas, Brazil
}

This paper provides an alternative view of monetary sovereignty (MS) from the NeoChartalist approach found in the Modern Money Theory literature. The differences between the author's approach to MS and Neo-Chartalism cover the following aspects: the nature of money, the acceptability of money, and the relationship between the central bank and the Treasury. The paper then analyses the relationship between MS, the currency hierarchy $(\mathrm{CH})$, and policy space. The focus is placed on emerging-market economies. It is argued that emerging-market economies' policy space is determined by the interplay of two factors: the degree of MS and the position of national money (that encompasses the state and bank monies) within the $\mathrm{CH}$.

Keywords: monetary sovereignty, currency hierarchy, policy space, Modern Money Theory, Post-Keynesian theory, emerging-market economies

JEL codes: $E 42, F 41, F 62$

\section{INTRODUCTION}

This paper provides an alternative view of monetary sovereignty (MS) to the NeoChartalist approach found in the Modern Money Theory (MMT) literature. The differences between our approach to MS and Neo-Chartalism cover the following aspects: the nature of money, the acceptability of money, and the relationship between the central bank and the Treasury. The argument is that the nature of money should cover not only its function as a unit of account and the credit-debt relation but also the function of money as an asset. Further, the paper sustains that the demand for money (that is, its acceptability) is not purely driven by taxes but also by monetary contracts and conventions. Finally, it contends that, among other functions, the Treasury gives credibility to central banks' liabilities while the central bank ensures that bank money will be traded at a par with state money, besides acting as the regulator of the financial system and the lender of last resort.

The paper then analyses the relationship between MS, the currency hierarchy $(\mathrm{CH})$, and policy space. The focus is placed on emerging-market economies. While the

* Email: daniela.prates@un.org. 
literature on the $\mathrm{CH}$ (for example, Paula et al. 2017) has stressed that the position of emerging-market economies' currencies at the bottom of such a hierarchy constrains their policy space, the paper argues that emerging-market economies' policy space is determined by the interplay of two factors: the degree of MS and the position of national money (that encompasses the state and bank monies) within the $\mathrm{CH}$.

The discussion is divided into six sections. Section 2 presents the MMT approach on MS, and its implications for policy space and exchange-rate regimes. Section 3 presents an alternative concept of MS to that of Neo-Chartalism coherent with the PostKeynesian (PK) approach to money developed by Davidson (1972), Minsky (1986), and other PK authors. ${ }^{1}$ Section 4 discusses the implications of the $\mathrm{CH}$ for exchange-rate dynamics, the actual exchange-rate regimes, and the policy space of emerging-market economies in the current monetary and financial international system. Section 5 develops a framework to analyse the relationship between MS, the $\mathrm{CH}$, and policy space in this setting. Section 6 concludes.

\section{THE MMT APPROACH ON MONETARY SOVEREIGNTY AND ITS IMPLICATIONS FOR POLICY SPACE AND EXCHANGE-RATE REGIMES}

There are four key assumptions underlying MMT's concept of sovereign currency (and MS) (see Wray 2015). The first is that sovereignty refers to political sovereignty, the original and most well-known definition of sovereignty. In that sense, state and sovereign are synonymous and sovereignty could be defined as the full right and power of the state to govern its territory without any interference from outside. ${ }^{2}$

The second assumption concerns the nature of money. Money refers to the money of account and comes into existence by definition of the state (that is, the sovereign government). Government obligations are then imposed on this money of account. Only afterwards is the state able to issue national fiat currency (that is, the sovereign currency) that responds to this definition, being also denominated in the same money of account.

The third assumption relates to the acceptability of money. For MMT, 'taxes drive money,' that is, because anyone with tax obligations must use the sovereign currency to eliminate these liabilities, such currency is in demand and thus can be used in purchase or payment of private commitments. According to Wray $(2015$, p. 51), there is no need to 'back' the currency with metal or enforce legal tender laws for its acceptance; 'all the sovereign government needs to do is to promise "This note will be accepted in tax payment" in order to ensure general acceptability domestically and even abroad.' 3

1. MS is a multidisciplinary and controversial concept. Many definitions have been proposed both in economics (for example, Mundell 1997) and in other fields of knowledge, such as sociology (for example, Dodd 2010), law (for example, Pistor 2017), and international political economy (for example, Cohen 1998). In this paper, we focus on the debate among PKs.

2. For more details on the concept of sovereignty, see Philpott (2016).

3. Although in this quotation Wray (2015) states that taxes drive money 'domestically and even abroad,' he does not explain how the obligation for paying taxes to a government in its sovereign currency will result in the acceptance of the currency abroad. Regarding the acceptance of government currency domestically, according to Tymoigne and Wray (2015, p. 29) MMT is agnostic 'as it waits for a logical argument or historical evidence showing that there is an alternative to taxes (and other obligations).'. 
The fourth assumption is that sovereign governments, as monopoly issuers, cannot become insolvent in their own currency. They are not subject to either default risk or to the budget constraints that apply to a currency user (except those they impose on themselves, that is, through budgeting, debt limits, or operating procedures). Such governments can afford anything they can purchase in their own currency and 'make any payments that come due, including interest payments on their debt and payments of principal crediting bank accounts' (ibid., p. 135).

This means that 'new created-money is the source of all government financing' (Bell 1998, pp. 2-3) and that sovereign governments need 'neither taxes nor bonds' to finance government spending (Bell and Wray 2002/2003, p. 269). For MMT, the government 'must spend (or lend) its currency before it can receive it back either in payment of taxes or in purchases of its debt. It does not really need to "borrow" in its own currency, as it can always spend by crediting bank accounts' (Mitchell et al. 2019, p. 338). This is because

the spending logically comes first before government obtains tax revenue or sells bonds. If the government receives in tax payments its own IOUs, it must first supply them before taxes can be paid. And if bond purchasers must use the government's IOUs to pay for the bonds they buy, then government must have spent (or lent) its IOUs before it sold the bonds. (Wray 2014, p. 29$)^{4}$

The proceeds from taxation and bond sales 'are not even capable of financing government spending since their collection implies their destruction' (Bell 1998, p. 3).

Taxes and bonds have other purposes. As Bell (2000, p. 614) summarizes, taxes can be viewed as a means of creating and maintaining the demand for the government's money (the aforementioned third assumption), 'while bonds, which are used to prevent deficit spending from flooding the system with excess reserves, are a tool that allows positive overnight lending rates to be maintained.' Hence, bond sales are 'a part of monetary policy, and not a required part of a fiscal policy' (Mitchell et al. 2019, p. 326). Taxes also have other roles: to drain reserves of the monetary system and, when the economy is at full employment, to contain excess demand.

Wray (2015) uses the concept of the 'pyramid of liabilities' to explain the difference between sovereign and non-sovereign currencies (see Figure 1). The main underlying idea is Minsky's statement that 'anyone can create money, the problem lies in getting it accepted.' From this perspective, embraced by MMT, money is an 'I owe you' (IOU).

Although governments, banks, firms, and households can create IOUs denominated in the unit of account created by the state, they are not equally acceptable. The pyramid is a hierarchical arrangement (for this reason, Bell 2001 calls it 'hierarchy of money' (p. 149)), where the liabilities issued by those higher in the pyramid are generally more acceptable and have higher creditworthiness. In the case of a sovereign government that issues a sovereign currency, ${ }^{5}$ the government's IOU occupies the first tier of the hierarchy exactly because it is accepted for tax payment (ibid., p. 160).

4. In the MMT textbook published in 2019 (Mitchell et al. 2019) it is recognized that 'under current procedures in many countries governments may choose to sell bonds before spending' (p. 338). They also state that if the central bank buys Treasuries' securities in the open market (currently, the institutional arrangement in place in most countries), the final result is the same as if they had bought them directly in the primary market. For a detailed explanation, see section 20.4 of Mitchell et al. (2019).

5. The sovereign currency refers to high-powered money, that is, monetary basis and bank reserves. 


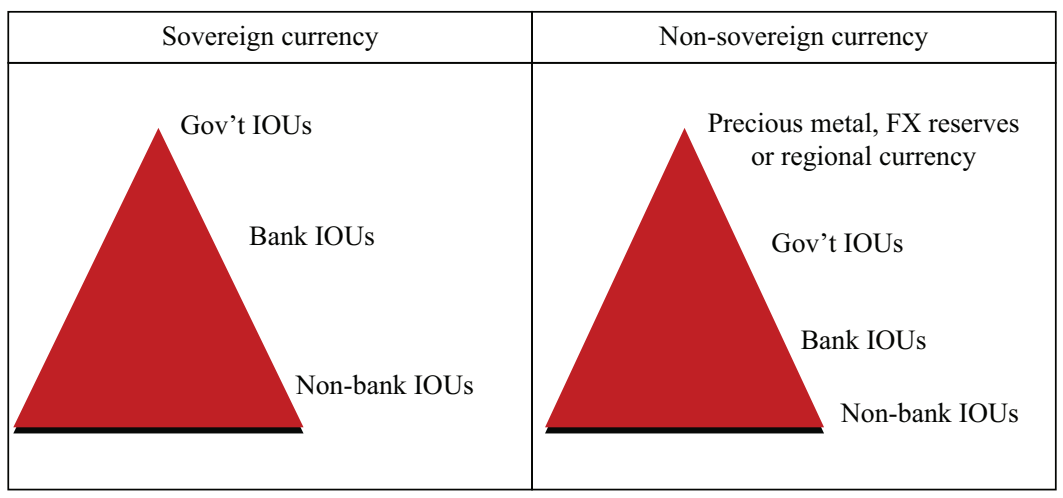

Source: Author's elaboration based on Wray (2015).

\section{Figure 1 Pyramid of liabilities}

Banks' IOUs (demand deposits) are placed in the second tier of the pyramid and accepted as means of payment as well, including for tax payment. As Bell (2001, p. 160) states, on the basis of Knapp (1905), banks' promises are nearly as liquid as state money and occupy this tier not only because 'the Central Bank guarantees that demand deposits will trade at par with government currency, but also because they are accepted in payment of taxes.'

The acceptance of banks' demand deposits in tax payments is also stressed by Mitchell et al. (2019, p. 155). They state that 'the government will also accept some kinds of bank liabilities [that is, demand deposits] in payment of taxes' (ibid.). ${ }^{6}$ Indeed, 'private banks intermediate between taxpayers and government, making payments in currency (reserves) on behalf of the taxpayers' (ibid., p. 157). Then, as a last resort, 'the state actually accepts only its own liabilities in payment to itself' (Bell 2001, p. 160). ${ }^{7}$

Hence, a sovereign government issues a sovereign currency that is necessarily fiat or non-convertible, being positioned at the top of the 'pyramid of payments' as it makes no promise to exchange it for a precious metal, or a foreign currency. Conversely, a government that operates with a foreign currency or a domestic currency convertible into a foreign currency (or to a precious metal) issues a non-sovereign currency and is subject to budget constraints and can face a solvency risk. Thus, the existence of convertibility constrains a country's use of its policy space to achieve economic and social goals, such as full employment, lower inequality, and sustained economic growth.

Wray (2015) points out that the benefits derived from having a sovereign current applies to both developed and developing sovereign countries. However, he explicitly recognizes that 'many developing countries will not find foreign demand for their domestic currency liabilities' (ibid., p. 124). If they run a continuous currency account deficit, they must issue liabilities denominated in one of the more highly desired currencies and will likely run into debt service problems in the future. Among these

6. For a detailed explanation of the use of banks' demand deposits as means of payment for MMT, see section 9.4 of Mitchell et al. (2019).

7. This kind of statement leads many scholars to understand that banks' IOUs are not accepted in payments of taxes for MMT. This is one example of what Lavoie (2013) calls 'problems of terminology' in Neo-Chartalism. 
highly desired currencies, the US dollar stands out, followed by other developed nations' currencies.

After recognizing this difference between developed and developing nations, Wray (2015) analyses policy strategies that developing nations could adopt to increase their policy space. Firstly, their governments should not issue foreign currency bonds because liabilities denominated in other currencies result in default risk and constrain domestic monetary policy. Secondly, the degree of policy space of developing countries with sovereign currencies will depend on the exchange-rate regime adopted.

In the analysis of the alternative regimes available to developing countries, Wray (2015, p. 129) recalls the well-known trilemma, according to which 'government can choose only two out of the following three: independent domestic policy, fixed exchange rate, and free capital flows.' He supports that a floating exchange rate ensures greater policy space for a developing country issuer of a sovereign currency. The country could face exchange-rate pressures, as changes in foreign portfolio preferences can lead to currency depreciation. 'But so long as the currency is floating, the government does not have to take further action if this happens' (ibid., p. 121).

According to Wray (2015), MMT supports floating rates to promote domestic policy space and not to close imbalances, that is, to adjust the balance of payments, as in the mainstream formulation of the trilemma. ${ }^{8}$ He states that it is

misleading to call a current account deficit an 'imbalance'; by definition it is balanced by the capital account flows. In that sense, it 'takes two to tango': a nation cannot run a current account deficit unless someone wants to hold its IOUs. We can view the current account as resulting from the rest-of-the-world desire to accumulate net savings in the form of claims on the country. (Ibid., pp. 130-131)

Contrarily to the case of the floating exchange-rate regime, a fixed exchange rate reduces policy space: the government can purchase any bundle of goods in its own currency, but must maintain sufficient FX reserves and use fiscal and monetary policy to sustain its peg. Moreover, as the budget deficit could put pressure on the exchange rate, there is some justification in attempting to avoid budget deficits through a tighter monetary policy stance. Nevertheless, developing countries with a sovereign currency that have fixed exchange rates can increase policy space either by increasing foreignexchange reserves or by protecting the existing level of reserves through the imposition capital controls. Managed floating is an intermediary position: the government can afford the purchase of any bundle of goods and services but, at the same time, must be wary of the effects on its exchange rate since monetary and fiscal policies could generate pressure that would alter the exchange-rate parity outside the desired range.

As Figure 2 summarizes, a country with a sovereign currency can have different exchange-rate regimes (floating, managed, or fixed). ${ }^{9}$ A floating exchange rate

8. Mundell (1963) puts forward the original formulation of the trilemma or impossible trinity that afterwards was presented in the so-called IS-LM-BoP models of open macroeconomics. In these models, the floating exchange rate ensures the adjustment of the balance of payments and the autonomy of monetary policy.

9. It is unclear what is the definition of a floating exchange-rate system for MMT. Most authors understand that in Wray (2015) and previous MMTers' texts it refers to a pure or free-floating system (see, for instance, Lavoie 2013; 2014). In Wray (2015), the reference to the trilemma endorses this understanding, shared herein, since in the trilemma there are only two exchange-rate systems (fixed and free-floating). Moreover, Wray (2015) distinguishes the floating exchange rate and the managed exchange rate. Yet, Mitchell et al. (2019, p. 14) state that, although after 1971 most currencies float freely against each other, occasionally 'central banks would conduct what became 


\begin{tabular}{|c|c|c|c|}
\hline Non-sovereign currency & \multicolumn{3}{|c|}{ Sovereign currency } \\
\hline $\begin{array}{c}\text { FX, convertible currency, } \\
\text { and monetary unions }\end{array}$ & $\begin{array}{c}\text { Fixed } \\
\text { exchange rate }\end{array}$ & $\begin{array}{c}\text { Managed exchange } \\
\text { rate }\end{array}$ & $\begin{array}{c}\text { Floating exchange } \\
\text { rate }\end{array}$ \\
\hline & Degrees of policy space \\
\hline Lower & & $\begin{array}{c}\text { Higher } \\
+\end{array}$ \\
\hline
\end{tabular}

Note: a. Countries that are members of monetary unions (such as the euro area), which do not issue their own fiat currency.

Source: Author's elaboration based on Wray (2015).

\section{Figure 2 Monetary sovereignty, exchange-rate regimes, and policy space}

provides the widest policy space. Wray (2015) also stresses that the principles of functional finance (Lerner 1943) apply most directly to a sovereign nation operating with a floating currency exactly because it has the highest degree of policy space, that is, 'whatever level the deficit or the public debt achieves, the central bank can always intervene and keep the interest rates at a stable level, and it cannot run out of foreign reserves since it does not attempt to peg the exchange rate' (Lavoie 2014, p. 497). On the contrary, a country with a non-sovereign currency does not have MS and has a lower policy space as it needs to borrow (to spend) and is thus prone to default risk. ${ }^{10}$

\section{A POST-KEYNESIAN CONCEPT OF MONETARY SOVEREIGNTY}

This section provides a summary of critical remarks by PK authors on the theoretical foundations of MMT's view of MS. On the basis of this assessment we present an alternative approach to MS. ${ }^{11}$

Rochon and Vernengo (2003) agree with the emphasis placed by MMT on the money of account function and on the fact that modern money is ultimately Chartal money (second assumption). However, they disagree that 'taxes drive money' (third assumption), underscoring the role of contracts in the acceptability of money (based on Keynes 1930 and Davidson 1972).

known as a "managed" float where they tried to limit the amplitude of movements the free float would generate.' Hence, in the MMT textbook, the floating exchange-rate system seems to include both the floating and the managed exchange rate.

10. The relationship between MS and exchange-rate regimes is also blurred in MMT. MMTers' works prior to Wray (2015) argue that a country with a fixed exchange rate does not have a sovereign currency (Wray 1998; 2002; Tcherneva 2006), leading to Lavoie's (2013) conclusion that, for Neo-Chartalism, there would be degrees of monetary sovereignty, the higher one being achieved in a regime of pure floating exchange rate. Bonizzi et al. (2019), based on Fazi and Mitchell (2019), include the floating exchange rate as an element of MS. Some passages of Mitchell et al. (2019) endorse such an interpretation.

11. This section addresses only the issues related to the concept of MS. Then, the so-called consolidation hypothesis (the consolidation of the balance sheets of the Treasury and the central bank) will not be addressed since it is not a necessary condition for MS according to the MMTers themselves (see, for instance, Bell 2000; Tcherneva 2011; Wray 2011). 
Keynes (1930) stresses this very same role: debts and prices and general purchasing power are expressed in the money of account. This is the primary concept of a theory of money because money itself,

namely that by delivery of which debt contracts and price contracts are discharged, and in the shape of which a store of general purchasing power is held, derives its character from its relationship to the money of account, since the debts and prices must first have to be expressed in terms of the latter. (Ibid., p. 3)

For Keynes, money does not emerge from the act of exchange (as in the orthodox economic theory), but is mainly a means for accounting and settling debts. In other words, an abstract money of account is a precondition for the existence of a monetary economy, being logically prior to that of the other functions of money.

Davidson (1972) delves deeper into the relationship between money and contracts. He argues that the 'synchronous existence of money and money contracts over an uncertain future is the basis of a monetary system,' because money could link the present to the future 'only if there is continuity over time of contractual commitments denominated in monetary units' (ibid., p. 142) that 'permits the sharing of some of the burdens of uncertainty between the contracting parties' (ibid., p. 146). Yet the existence of institutions, normally operating under the aegis of the state, is necessary to enforce the discharge of these commitments. Indeed, it is "with the development of such state-sponsored institutions, that the government appropriated to itself the right to define what is the unit of account and what thing should answer that definition' (ibid., p. 146). Hence, the sine qua non condition for the existence of a monetary economy is private contracts for spot and deferred settlements denominated in the money of account defined by the state and discharged by the thing the state defines as the economy's money (state money and bank money), which differs from the obligation to pay taxes to the government, which are debt contracts between private agents and the state.

Another critical attribute, in Davidson's (1972) view, is confidence: if the community lost confidence in the ability of state institutions to enforce contracts, the monetary system would break down. More broadly, the origin and acceptability of money also depend on social conventions (also stressed by Rochon and Vernengo 2003). As Dequech (2013, p. 253) points out, money 'is an institution itself and is closely related to organizations and other institutions,' among which are conventions. The conventional character of money is mainly related to acceptability and was stressed by Chick (1983), Davidson (1972), Harrod (1969), and Keynes (1930; 1936). ${ }^{12}$

Other authors call into question the paradoxical claim that taxes and bonds do not and cannot finance government spending. As Lavoie (2013, p. 9) stressed, any agent 'must have funds in a banking account: Before being able to spend, the treasury must somehow replenish its deposit account at the central bank (or at private banks).'

Fiebiger (2012a, p. 3) provides a more extensive critique of this key claim of MMT:

Transfers out of (or into) the Treasury's account at the central bank will increase (or decrease) the quantity of bank reserves and, hence, the quantity of HPM [high-powered money]. But it will not affect the amount of central bank liabilities because bank reserves and Treasury deposits are both liabilities of the central bank. When the Treasury spends the

12. Such a character is also stressed by Aglietta and Órlean (2002). 
transaction only alters the composition of central bank liabilities and, therefore, is not money creation.

Then, proceeds from taxes or bonds paid into the Treasury's account are not 'destroyed' (Bell 1998), but 'increase the deposit balance that the Treasury then draws on to pay for things' (ibid., p. 3). ${ }^{13}$

Minsky (1986, pp. 55-56), in turn, highlights the importance of taxes and bonds not only to finance government expenditures, but also as key pillars underlying the acceptability of state money. In his view, the purpose of taxes is not to create a demand for currency. Taxes finance government expenditures and give credibility to the central bank (CB) liability, since the CB assets of most countries are mainly Treasury securities that are ultimately valuable because the government has a source of revenue.

Minsky (1986) also refers to the role of the CB as regulator of the financial system and lender of last resort, ${ }^{14}$ and to the role of the Treasury as the issuer of government securities - which are crucial tools of big government not only because they finance state expenditures in recessions, but also because they are acquired by financial and non-financial agents to store financing power.

At this point, we have the elements to present what we call a PK concept of MS (see Table 1) alternative to the Neo-Chartalist one. As in the MMT concept, sovereignty refers to political sovereignty. There are, however, differences regarding the approach to money. In the PK concept proposed herein, money is money of account, a creditdebt relation and an asset, being accepted because it is both a convention and a creature of the state. ${ }^{15}$ Since taxes are a class of monetary contracts, the version of the 'state theory of money' focusing on contracts (led by Davidson 1978) is more general than the 'taxes-drive-money view' (that is, MMT).

As in the case of political sovereignty, monetary sovereignty is a claim that must be recognized by others if it is to have any meaning, that is, it requires reciprocal recognition. The CB and the Treasury are essential for the acceptability of national fiat money (encompassing state money and bank money, convertible at par into state money), that is, for a country to have monetary sovereignty. Yet, as Fiebiger (2012b, p. 28) points out, they are dissimilar institutions: 'Whereas the central bank finances all of its activities by issuing money, and does not raise revenues by taxation or debt issuance, the Treasury basically does the opposite.'

State-sponsored institutions enforce contracts and the Treasury enforces tax laws, besides being responsible for the fiscal policy. Taxes and Treasury bonds finance the Treasury expenditures. The Treasury expends by depleting its existing deposit balances (obtained through taxations and bonds' sale) in its account at the CB. Moreover, as Minsky argues, these bonds are a counterpart of the CB liability, which is ultimately valuable because the government collects taxes. In the stage of money-manager capitalism, these bonds are also a safe haven for private wealth, that is, the lower-risk securities demanded for storing financing power.

13. For a more detailed explanation, see also Fiebiger (2012b).

14. As Epstein $(2019$, p. 6) stresses, MMTers 'talk very little ... about the necessary role of financial regulations ... . This lacuna is puzzling in view of MMT theorists' long-standing association with the work of Hyman Minsky' and 'is a key example of their relative inattention to institutional and empirical constraints on the macroeconomic policies they propose.'.

15. It is worth mentioning that Wray $(2015$, p. 47) explicitly rejects the role of conventions in the acceptability of money. He calls the conventional approach on money a 'silly theory' that relies on an 'infinite regress.'. 
Table 1 Concepts of monetary sovereignty in comparison

\begin{tabular}{|c|c|c|c|}
\hline & & Post-Keynesian & Neo-Chartalist \\
\hline & \multicolumn{3}{|c|}{ Common pillars } \\
\hline 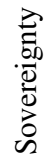 & $\begin{array}{l}\text { Political } \\
\text { sovereignty }\end{array}$ & \multicolumn{2}{|c|}{$\begin{array}{l}\text { The national state is the sovereign that has the full right and power to } \\
\text { govern its territory without any interference from outside sources or } \\
\text { bodies }\end{array}$} \\
\hline \multirow[b]{4}{*}{ 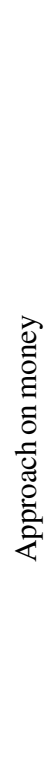 } & \multicolumn{3}{|c|}{ Different pillars } \\
\hline & Nature of money & $\begin{array}{l}\text { Money of account, credit-debt } \\
\text { relation, and asset }\end{array}$ & $\begin{array}{l}\text { Money of account and credit- } \\
\text { debt relation }\end{array}$ \\
\hline & $\begin{array}{l}\text { Acceptability } \\
\text { of money }\end{array}$ & $\begin{array}{l}\text { Monetary contracts, taxes and } \\
\text { conventions drive the national } \\
\text { fiat money (state/central bank } \\
\text { money and bank money) }\end{array}$ & $\begin{array}{l}\text { Taxes drive the national fiat } \\
\text { money (state money/sovereign } \\
\text { currency and bank money) }\end{array}$ \\
\hline & $\begin{array}{l}\text { Central bank } \\
\text { and Treasury } \\
\text { nexus }\end{array}$ & $\begin{array}{l}\text { Treasury: enforces tax laws; taxes } \\
\text { and bonds finance government } \\
\text { expenses and give credibility to } \\
\text { the central bank liability (the } \\
\text { state money) } \\
\text { Central bank: issues the state } \\
\text { money and guarantees that bank } \\
\text { money will be traded at par } \\
\text { with state money; responsible } \\
\text { for the monetary policy, lender } \\
\text { of last resort, and regulator of } \\
\text { the monetary and financial } \\
\text { system; has the ultimate ability } \\
\text { to monetize the public debt }\end{array}$ & $\begin{array}{l}\text { Treasury: spends by crediting a } \\
\text { bank account and faces no } \\
\text { financial constraint and default } \\
\text { risk; taxes and bonds do not and } \\
\text { cannot finance gov. expenditures } \\
\text { Central bank: finances the } \\
\text { Treasury and determines the } \\
\text { policy rate based on Treasury } \\
\text { bonds (an interest-bearing } \\
\text { alternative to reserves). Taxes } \\
\text { also have the purpose of } \\
\text { draining reserves }\end{array}$ \\
\hline
\end{tabular}

Source: Author's elaboration.

The CB issues state money and guarantees that demand deposits (bank money) will trade at par with it. It is also responsible for monetary policy, that is, for controlling the market of reserves and determining the policy rate based on a set of instruments, among which are Treasury securities. As Gnos and Rochon (2002, p. 53) claim, sovereignty over money also requires the control of the national state over money markets that is grounded on the CB's ability to manipulate interbank settlements.

The CB is the lender of last resort and the regulator of the monetary and financial system. Those are key roles for curbing asset-price inflations and credit bubbles, thus ensuring domestic monetary and financial stability and the reproduction of the convention of acceptability - which are preconditions for the stability of money. While these roles are recognized by MMTers (for example, Mitchell et al. 2019 and Wray 2015), they are not considered pillars of MS as in the PK concept proposed herein. Finally, the $\mathrm{CB}$ as the issuer of the state money has the ultimate ability to monetize public debt. This is the reason why a country cannot default in its own currency. However, the effective monetization of public debt is bounded in money-manager capitalism (Minsky 1986) by the market constraints and reactions (Palley 2019). 


\section{THE CURRENCY HIERARCHY, EXCHANGE-RATE DYNAMICS, AND POLICY SPACE}

MMT has also been criticized by PK scholars for neglecting open-economy considerations, for focusing too much on the case of the US, the issuer of the key currency (the US\$) (for example, Cesaratto 2012; Palley 2015a; Rochon and Vernengo 2003) and/or for disregarding developing (or peripheral) economies' specificities, such as the existence of external constraints, the implications of the $\mathrm{CH}$ for exchange-rate dynamics, the actual exchange-rate regimes, and the policy space of those economies (Bonizzi et al. 2019; Epstein 2019; Vergnhanini and De Conti 2017; Vernengo and Caldentey 2019). In this section we summarize those implications on the basis of a Post-Keynesian-Structuralist approach on the CH (Andrade and Prates 2013; Paula et al. 2017). ${ }^{16}$

The PK literature (Harvey 2009) highlights that, in the post-Bretton Woods era, short-term capital flows - subordinated to a speculative logic - have been the chief determinant of nominal exchange rates that are highly volatile. With the exception of the US (the issuer of the key currency), all countries face an 'impossible duality' (Flassbeck 2001) or a 'dilemma' (Rey 2013), and not an 'impossible trinity' or a 'trilemma,' as Wray (2015) argues. This means that free capital mobility implies loss of monetary policy autonomy, independently of the exchange-rate regime adopted, and that 'independent monetary policies are possible ... only if the capital account is managed regardless of the exchange-rate regime' (Rey 2013, p. 21).

In practice, following the crisis of the fixed or managed exchange-rate regimes of the 1990s and the early 2000s, most of the emerging-market economies have adopted de facto dirty floating rather than floating exchange-rate regimes. Yet these economies face a greater dilemma than the center ones due to the macroeconomic asymmetry of the current international monetary and financial system (IMFS), that is, their lower degree of policy space in comparison to center economies (Andrade and Prates 2013; Ocampo 2001).

Both the higher exchange-rate volatility and the macroeconomic asymmetry stem from the monetary and financial asymmetries prevailing within the current IMFS. These asymmetries have gained importance after Bretton Woods, overlapping with the technological and productive ones highlighted by the Structuralist literature (Ocampo 2001).

The monetary asymmetry is a consequence of the $\mathrm{CH}$, that is, of the hierarchical structure of an IMFS organized around a national currency that becomes its so-called key currency (Keynes 1930; 1944).

Currencies are hierarchically positioned according to their degree of liquidity $(l)$, which relates to their ability to perform the three functions of money internationally. The key currency (currently, the fiduciary and flexible US dollar) has the highest liquidity premium as it performs the three functions of money internationally (means of payment, unit of account, and store of value). Below the key currency stands the euro and, subsequently, the currencies issued by the other center countries - also liquid currencies, but with a smaller liquidity premium than the key currency, because they perform the functions only partially. At the opposite end, we find the peripheral currencies issued by emerging-market economies, whose liquidity premium is the

16. Bonizzi et al. (2019) and Vernengo and Caldentey's (2019) critical assessment of MMT's approach to developing economies also builds on the Post-Keynesian and Structuralist literatures and complements the analysis of this section. 
lowest, as they do not - or only marginally - perform the functions internationally (Andrade and Prates 2013).

Yet the degree of currency internationalization (Cohen 1971) ${ }^{17}$ is only a proxy for the position of the currency in the $\mathrm{CH}$. As Orsi (2019) argues, the linear relationship between them presupposes that such a position will be equally influenced by each of the international functions. In order to depict an accurate $\mathrm{CH}$, it would be necessary to also consider the type of internationalization. More specifically, the demand for peripheral currencies as short-term investment currencies does not stem from a greater confidence from global investors due to an increase in their liquidity premium, but reflects a lower liquidity preference of these investors. Then, it is necessary to distinguish the demand for a currency with the aim of obtaining speculative gains in the short term from the demand for a long-term store of value (which is the case of central currencies with a higher liquidity premium).

Besides the differentiation proposed by Orsi (2019), the importance of each money function is different in Cohen's and the Post-Keynesian-Structuralist approach. This difference, in turn, is directly associated with the determinants of the emergence of a key currency (top currency, in Cohen's terms) and other international currencies in each approach.

Despite recognizing the role of states in shaping the geography of money, Cohen (1998) claims that this 'distinguished elite' of currencies became international through a 'demand-driven process of natural selection' (ibid., p. 29) that was fostered by network externalities and economies of scale. This market-based process selects some currencies as a medium of exchange that will facilitate international transactions. Underlying the explanation of the emergence of international currencies stands the orthodox approach on money, according to which the market precedes money, which is a medium that emerges from exchanges (see Section 3). Consequently, the original and most important function is as medium of exchange. ${ }^{18}$

Contrarily, the approach followed here shares the perspective of some International Political Economy (IPE) scholars (mainly, Helleiner 1994; Strange 1988), according to which the states' power relations are the main determinants of the asymmetric use of national currencies at the international level. Yet it is necessary to link this perspective with the PK theory of money (see the last section) in which the function of money of account is the primary concept. Coherently with such a theory, at the international level, money is primarily a means for accounting and settling debts. An abstract money of account is a precondition for the existence of an international monetary economy and is logically anterior to the other functions of money. Or, paraphrasing Davidson (1972), the sine qua non condition for the existence of an international monetary economy is private contracts for spot and deferred settlements denominated in the money of account.

Internationally, however, it is the currency of the hegemonic state (currently, the US) that performs the role of international money of account and, consequently, the

17. Cohen (1971) proposed that this degree depends on the uses of currencies at the international level as a unit of account, means of exchange, and store of value for both private and official agents, which results in six functions. The concept of original sin (Eichengreen et al. 2007) is a more limited concept as it stems from the incapacity of currencies issued by emergingmarket economies to perform one function of money at the international level: the unit of account of international debt.

18. For a detailed critique of the approach on money underlying the dominant view in the IPE literature, see Fields and Vernengo (2011). 
other functions of money. As Fields and Vernengo (2011) stressed, the hegemon must provide a secure asset free of default risk to the system (the US Treasury bonds), which is a key pillar of what Strange (1988) called the 'structural power' of the US.

\section{MONETARY SOVEREIGNTY, THE CURRENCY HIERARCHY, AND POLICY SPACE}

$\mathrm{CH}$ has proven to be even more deleterious after the emergence of financial globalization due to a two-dimensional financial asymmetry. Firstly, as capital flows ultimately depend on external factors, emerging-market economies (that is, the peripheral countries that have engaged in such globalization) have become even more vulnerable to their inherent volatility. Secondly, although the share of emerging-market economies' assets in the portfolios of global investors has been increasing since the 1990s, these economies still have a marginal insertion in global capital flows, which also contributes to this higher vulnerability, as these flows exercise important pressures on their currency and financial markets due to their small relative size (Paula et al. 2017).

The monetary and financial asymmetries provide significant macroeconomic challenges for emerging-market economies. In periods of booms of capital flows, peripheral currencies and financial assets become objects of desire for global investors. In this setting, huge financial inflows result most often in currency appreciation, asset inflation, and credit bubbles. Conversely, in bust phases (that is, moments of changes in monetary conditions in the center and/or high liquidity preference of global investors), those currencies and assets turn out to be the main victims of global investors' 'flight to quality.'

Moreover, currency depreciations have more harmful macroeconomic effects in developing countries because of the risk of financial fragility due to potential currency mismatches and reversal of portfolio investments. Besides, the pass-through of exchange-rate changes to domestic prices is higher as the current and expected behavior of the exchange rate becomes a key parameter of corporations' price setting. Also, Palley $(2015 \mathrm{a}$; 2015b) and Vernengo and Caldentey (2019) stress that the greater influence of the exchange rate on inflation in those economies (mainly Latin American ones) are associated with structural features highlighted by the Structuralist literature (such as a significant dependence on imported inputs and capital goods).

Hence, if we consider the actual monetary, financial, and macroeconomic asymmetries of the current IMFS, we come to very different conclusions from Wray's (2015) one regarding the relationship between policy space and exchange-rate regimes in emerging-market economies.

Floating exchange-rate regimes are not feasible and do not deliver a greater policy space, especially in those economies whose currencies are positioned at the bottom of the CH. Indeed, the fear of floating (Calvo and Reinhart 2002) is a consequence of the monetary and financial asymmetries and of the greater dilemma faced by such economies in comparison to center countries (Paula et al. 2017). ${ }^{19}$ If we consider Mitchell et al.'s (2019, p. 14) definition of a floating exchange-rate system (see footnote 9 in the present paper), the same conclusion applies. Emerging-market economies' central banks do not intervene occasionally in the currency markets to 'limit the amplitude of movements the free float would generate' (Mitchell et al. 2019, p. 14), but adopt

19. As Lavoie (2014) points out, many PKs are in favor of fixed exchange rates because of the adverse effects of exchange-rate instability. 
a dirty floating regime, that is, intervene frequently in these markets not only to curb the huge volatility of peripheral currencies, but also due to the precautionary demand for foreign-exchange reserves.

Furthermore, although Wray (2015) recognizes that floating exchange rates would not eliminate current-account imbalances, his analysis of the meaning of the current and capital accounts of the balance of payments (see Section 2) is misplaced. The equality of current and capital accounts (with the reverse sign) is an accounting identity that always holds ex post (such as the equality between saving and investment). Yet, as Borio and Disyatat $(2015$, p. 2) emphasize, the current account cannot tell whether a country is lending (if in surplus) or borrowing (if in deficit): 'The current account is simply telling us whether a country is, on net, releasing resources to the rest of the world (if in surplus) or drawing on it for resources. But the corresponding expenditures could be financed entirely at home or abroad regardless of the current account position' (emphases in the original). Such a misunderstanding is associated with the lack of distinction between saving and financing or between a resource and a financing (or cash-flow) constraint.

Consequently, current accounts do not unveil financing patterns. 'They reflect net wealth transfers, not financing flows' (ibid., p. 7). This means that current-account patterns and the corresponding net capital flows are not useful to capture the features of a country's financial integration in the current IMFS. These features stem from the dynamics of gross capital flows. ${ }^{20}$

In the case of emerging-market economies, the interplay between the monetary and financial asymmetries reinforces the impact of such dynamics on the currency, monetary, and financial markets. The composition of those flows is also important. Wray (2015) calls attention only to the indebtedness in foreign currencies that result in default risk and constrain domestic monetary policy, ignoring the negative consequences of non-resident institutional investors' portfolios in the domestic financial markets of emerging-market economies. The increasing participation of these global money managers in such markets makes these economies vulnerable to their allocation decisions driven by speculative gains or by the need of achieving target rates of return (Bonizzi 2017).

Hence, even if they are not indebted in foreign currencies, emerging-market economies are subject to the 'market discipline' imposed by portfolio investors, as the peripheral economies of the eurozone. Those countries, in turn, have become subject to 'market discipline' and to the pro-cyclical policies imposed by the so-called Troika in the context of the euro crisis, because they relinquished their MS when they joined the Economic and Monetary Union (EMU).

According to the PK concept proposed in this paper (see Section 3), the euro is not a sovereign currency. At the same time, the adoption of the euro has meant an immediate ascent in the $\mathrm{CH}$, especially for the countries of the eurozone periphery. Over the favorable phase of the international liquidity cycle prior to the global financial crisis (GFC), such an ascent translated into a significant fall in the interest rates demanded by global investors to acquire public and private debt securities, a lower exchange-rate volatility, and, consequently, a higher economic growth and lower unemployment.

20. As Bonizzi et al. (2019) point out, many MMT views on open-economy issues are similar to the conventional analysis, while others neglect the external constraints faced by developing countries (such as the statement that imports represent a real benefit to residents and exports a real cost, in Mitchell et al. 2019). 
When the euro crisis broke out, the negative repercussions of the loss of MS were brought to light.

Therefore, the experience of emerging-market economies and of peripheral economies of the euro area reveals that the degree of policy space in the current IMFS is associated with MS (as defined in the PK concept proposed in the last section) as well as to the position of the country's currency in the $\mathrm{CH}$. Further, regarding MS, there are countries that have neither a full-fledged nor a non-sovereign currency. That is the case with emerging-market economies that have a sovereign currency, yet face a degree of currency substitution, that is, a foreign currency also performs some functions of money at the domestic level. As depicted in Figure 3, the interplay of these two dimensions - (degrees of) MS and (position in) the $\mathrm{CH}$ - in the current IMFS results in six different situations regarding the degree of policy space.

The first three situations refer to center countries. The first is the case of the US, which, for having MS and being the issuer of the key currency, has the greatest degree of policy space. The second refers to the other center countries that have both international and sovereign currencies. The third concerns the eurozone countries that are at a higher position than the latter in the $\mathrm{CH}$ but face a lower policy space as they don't have MS. ${ }^{21}$

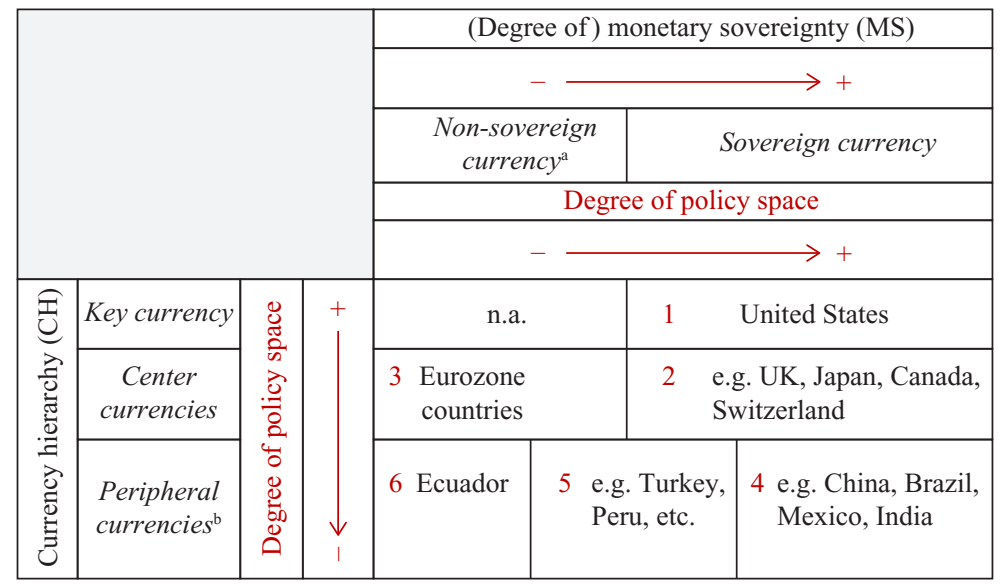

Notes: a. Countries that use a foreign currency, have a convertible currency, or are members of monetary unions. b. Based on the sample of emerging-market countries of the Institute of International Finance (IIF): Argentina, Brazil, Bulgaria, Chile, China, Colombia, Czech Republic, Ecuador, Egypt, Hungary, India, Indonesia, Korea, Lebanon, Malaysia, Mexico, Morocco, Nigeria, Peru, Philippines, Poland, Romania, Russia, Saudi Arabia, South Africa, Thailand, Turkey, Ukraine, United Arab Emirates.

Source: Author's construction.

Figure 3 The currency hierarchy, monetary sovereignty, and policy space: a PostKeynesian approach

21. The countries of the eurozone do not have the same degree of policy space due to what we could call an 'inside hierarchy without currencies' in which Germany is positioned at the top level and the peripheral economies at the bottom. It goes beyond the aim of this paper to analyse the factors underlying their different degrees of policy space. 
The other three situations concern the emerging-market economies' issuers of peripheral currencies, the focus of this paper. The fourth situation shows the countries that have a sovereign currency and, consequently, the greater degree of MS and policy space among emerging-market economies. At the fifth position stand the countries that have a sovereign currency but face a degree of currency substitution. Countries at the sixth situation do not have a sovereign currency (currently, only Ecuador in the sample used in this paper, where the US dollar has replaced the former domestic currency since 2000) and have the lowest degree of policy space among all countries.

Yet, in order to define the specific degree of policy space of each emerging economy that has MS but is positioned at a low level in the $\mathrm{CH}$, a next step would be necessary, as detailed in the final remarks.

\section{FINAL REMARKS}

The discussions on MS and policy space, on the one hand, and on the currency hierarchy and policy space, on the other, have evolved separately in the PK literature. Moreover, the concept of MS available (the Neo-Chartalist one) disregards key aspects of the PK theory of money.

In order to build a framework on the relationship between MS, the $\mathrm{CH}$, and policy space, firstly, the paper elaborates a PK concept of MS. This concept also has as a starting point the notion of political sovereignty, but distinguishes itself from the Neo-Chartalist one regarding: (i) the nature of money (unit of account, credit-debt relation, but also an asset) and its acceptability (driven by taxes but also by monetary contracts and conventions); (ii) the functions of the Treasury (enforcement of tax laws; expenditures financed by taxes and bonds that give credibility to the central bank liability, that is, the state money); and (iii) the functions of the central bank (issuance of state money; guarantor of the tradability at par of bank money and state money; responsible for the monetary policy, lender of last resort, and regulator of the monetary and financial system and the ultimate ability to monetize the public debt).

Secondly, the paper proposed an analytical framework according to which the degree of policy space in the current IMFS marked by monetary, financial, and macroeconomics asymmetries is determined by the interplay of (degrees of) MS and (position in) the $\mathrm{CH}$. The interplay of the two dimensions results in six different situations, among which two stand out: the case of the euro countries, whose currencies are positioned at a high level in the $\mathrm{CH}$, but have no MS; and the case of emerging-market economies that have MS, but are positioned at a lower level in the $\mathrm{CH}$.

Regarding the specific degree of policy space of each of those emerging-market economies, a more disaggregated kind of analysis (that is, case studies) would be necessary to identify three main factors that shape it.

The first is the relative position of its currency vis-à-vis other peripheral currencies in the $\mathrm{CH}$. Although the indicators presented by De Conti and Prates (2018) point to a higher degree of currency internationalization of the Chinese renminbi, the definition of this relative position requires an analysis of the type of currency internationalization. The second factor is the external constraint exactly because of the position of the peripheral currencies in the $\mathrm{CH}$.

The third factor is the 'macroeconomic regime' defined here as the interaction between the macroeconomic policies within an institutional framework. The exchange-rate regime, highlighted by Wray (2015), is only one of its lynchpins. The other one is the degree of financial openness that functions as a filter of international 
spillovers on the domestic performance and influences the effectiveness of the exchange-rate policy. The lower this degree, the higher the policy space of a peripheral economy.

\section{ACKNOWLEDGMENTS}

The author thanks Nathalie Marins, Simone Deos, Adriana N. Ferreira, Saulo C. Abouchedid, Bruno M. de Conti, Antônio Carlos M. e Silva, the anonymous referees, and the editors for comments on previous versions. Financial support from the Brazilian National Research Council (CNPq, Brazil) and the São Paulo State Research Foundation (Fapesp) is gratefully acknowledged.

\section{REFERENCES}

Aglietta, M. and A. Orléan (2002), La monnaie: entre violence et confiance, Paris: Odile Jacob.

Andrade, R. and D.M. Prates (2013), 'Exchange rate dynamics in a peripheral monetary economy,' Journal of Post Keynesian Economics, 35(3), 399-416.

Bell, S. (1998), 'Can taxes and bonds finance government spending?,' Working Paper No 244, July, The Jerome Levy Economics Institute.

Bell, S. (2000), 'Do taxes and bonds finance government spending?,' Journal of Economic Issues, 34(3), 603-620.

Bell, S. (2001), 'The role of the state and the hierarchy of money,' Cambridge Journal of Economics, 25, 149-163.

Bell, S. and L.R. Wray (2002/2003), 'Fiscal impacts on reserves and the independence of the Fed,' Journal of Post Keynesian Economics, 25(2), 263-271.

Bonizzi, B. (2017), 'An alternative Post-Keynesian framework for understanding capital flows to emerging markets,' Journal of Economic Issues, 51(1), 137-162.

Bonizzi, B., A. Kaltenbrunner, and J. Michell (2019), 'Monetary sovereignty is a spectrum: modern monetary theory and developing countries,' Real-World Economics Review, 89, 46-61.

Borio C. and P. Disyatat (2015), 'Capital flows and the current account: taking financing (more) seriously,' BIS Working Paper 525.

Calvo, G. and C. Reinhart (2002), 'Fear of floating,' Quarterly Journal of Economics, 117(2), $379-408$.

Cesaratto, S. (2012), 'A reply to Wray - part I,' Naked Keynesianism Blog, available at: http:// nakedkeynesianism.blogspot.com.br/2012/08/a-reply-to-wray-part-i.html (accessed 15 March 2018).

Chick, V. (1983), Macroeconomics After Keynes, Cambridge, MA: MIT Press.

Cohen, B.J (1971), The Future of Sterling as an International Currency, London: Macmillan.

Cohen, B.J. (1998), The Geography of Money, London and Ithaca, NY: Cornell University Press.

Davidson, P. (1972), Money and the Real World, London: Macmillan.

De Conti, B.M. and D.M. Prates (2018), 'The International Monetary System hierarchy: current configuration and determinants,' Discussion Paper 335, Institute of Economics, University of Campinas, Brazil.

Dequech, D. (2013), 'Is money a convention and/or a creature of the state? The convention of acceptability, the state, contracts, and taxes,' Journal of Post Keynesian Economics, 36(2), 251-273.

Dodd, N. (2010), 'Money, law, sovereignty,' Paper presented at Stockholm SGIR Conference, September.

Eichengreen, B., R. Hausmann, and U. Panizza (2007), 'Currency mismatches, debt intolerance, and the original sin: why they are not the same and why it matters,' in S. Edwards (ed.), 
Capital Controls and Capital Flows in Emerging Economies: Policies, Practices and Consequences, Chicago: University of Chicago Press, pp. 121-170.

Epstein, G. (2019), 'The institutional, empirical and policy limits of Modern Money Theory,' PERI Working Papers Series No 481.

Fazi, T. and W. Mitchell (2019), 'For MMT,' Tribune, available at: https://tribunemag.co.uk/ 2019/06/for-mmt.

Fiebiger, B. (2012a), 'Modern Money Theory and the "real-world" accounting of $1-1<0$ : the U.S. Treasury does not spend as per a bank,' Working Paper 279, PERI Working Paper Series.

Fiebiger, B. (2012b), 'A rejoinder to "Modern Money Theory: a response to critics",' Working Paper 279, PERI Working Paper Series.

Fields, D.M. and M. Vernengo (2011), 'Hegemonic currencies during the crisis: the dollar versus the euro in a Cartalist perspective,' Review of International Political Economy, 20(4), $740-759$.

Flassbeck, H. (2001), 'The exchange rate: economic policy tool or market price?,' Discussion Paper UNCTAD No 157.

Gnos, C. and L.-P. Rochon (2002), 'Money creation and the state: a critical assessment of Chartalism,' International Journal of Political Economy, 32(3), 41-57.

Harrod, R. (1969), Money, London: Macmillan.

Harvey, J.T. (2009), Currencies, Capital Flows and Crises: A Post Keynesian Analysis of Exchange Rate Determination, London: Routledge.

Helleiner, E. (1994), States and the Reemergence of Global Finance, from Bretton Woods to the 1990 s, Ithaca, NY and London: Cornell University Press.

Keynes, J.M. (1930 [2013]), The Treatise on Money, vols I and II, Cambridge, UK: Cambridge University Press.

Keynes, J.M. (1936 [1964]), The General Theory of Employment, Interest, and Money, London: Macmillan.

Keynes, J.M. (1944 [2013]), 'Activities 1941-46: the Clearing Union,' The Collected Writings of John Maynard Keynes, vol. XXV, Cambridge, UK: Cambridge University Press.

Knapp, G.F. (1905 [1973]), The State Theory of Money, New York: Augustus M. Kelley.

Lavoie, M. (2013), 'The monetary and fiscal nexus of neo-chartalism: a friendly critique,' Journal of Economic Issues, 47(1), 1-32.

Lavoie, M. (2014), Foundations of Post-Keynesian Economic Analysis, Cheltenham, UK and Northampton, MA: Edward Elgar Publishing.

Lerner, A.P. (1943), 'Functional finance and the federal debt,' Social Research, 10, 38-51.

Minsky, H. (1986), Stabilizing an Unstable Economy, New Haven, CT: Yale University Press.

Mitchell, W., R.L. Wray, and M. Watts (2019), Macroeconomics, London: Red Globe Press.

Mundell, R.A. (1963), 'Capital mobility and stabilization policy under fixed and flexible exchange rates,' The Canadian Journal of Economics and Political Science, 29(4), 475-485.

Mundell, R.A. (1997), 'Money and the sovereignty of the state,' Paper prepared for the International Economic Association Conference, Trento.

Ocampo, J.A. (2001), 'International asymmetries and the design of the international financial system,' CEPAL Serie Temas de Coyuntura No 15, Santiago de Chile: CEPAL.

Orsi, B. (2019), 'Currency internationalization and currency hierarchy in emerging economies: the role of the Brazilian real,' $\mathrm{PhD}$ Thesis, University of Leeds.

Palley, T.I. (2015a), 'Money, fiscal policy, and interest rates: a critique of Modern Monetary Theory,' Review of Political Economy, 27(1), 1-23

Palley, T.I. (2015b), 'The critics of Modern Money Theory (MMT) are right,' Review of Political Economy, 27(1), 45-61.

Palley, T. (2019), 'What's wrong with modern money theory (MMT): a critical primer,' FMM Working Paper 44, March.

Paula, L.F.R., B. Fritz, and D.M. Prates (2017), 'Keynes at the periphery: currency hierarchy and challenges for economic policy in emerging economies,' Journal of Post Keynesian Economics, 40(2), 183-202. 
Philpott, D. (2016), 'Sovereignty,' in E.N. Zalta (ed.), The Stanford Encyclopedia of Philosophy, available at: https://plato.stanford.edu/entries/sovereignty/ (accessed 25 May 2017).

Pistor, K. (2017), 'From territorial to monetary sovereignty,' Theoretical Inquiries in Law, 18(2), 491-517.

Rey, H. (2013), 'Dilemma not trilemma: the global financial cycle and monetary policy independence,' Paper presented at the Jackson Hole Symposium.

Rochon, L.-P. and M. Vernengo (2003), 'State money and the real world: or Chartalism and its discontents,' Journal of Post Keynesian Economics, 26(1), 57-68.

Strange, S. (1988), States and Markets, London and New York: Continuum.

Tcherneva, P.R. (2006), 'Chartalism and the tax-driven approach,' in P. Arestis and M. Sawyer (eds), A Handbook of Alternative Monetary Economics, Cheltenham, UK and Northampton, MA: Edward Elgar Publishing, pp. 69-86.

Tcherneva, P.R. (2011), 'Bernanke's paradox: can he reconcile his position on the federal budget with his recent charge to prevent deflation?,' Journal of Post Keynesian Economics, 33(3), 411-434.

Tymoigne, E. and R. Wray (2015), 'Modern Money Theory: a reply to Palley,' Review of Political Economy, 27(1), 24-44.

Vergnhanini, R. and B.M. De Conti (2017), 'Modern Money Theory: a criticism from the periphery,' Brazilian Keynesian Review, 3(2), 16-31.

Vernengo, M. and E.P. Caldentey (2019), 'Modern Money Theory (MMT) in the tropics: functional finance in developing countries,' Working Paper 459, PERI Working Paper Series.

Wray, R. (1998), Understanding Modern Money: The Key for Full Employment and Price Stability, Cheltenham, UK and Northampton, MA: Edward Elgar Publishing.

Wray, R. (2002), 'State money,' International Journal of Political Economy, 32(3), 23-40.

Wray, R. (2011), 'A modest proposal for ending debt limit gridlock,' Credit Writedowns, 7 March, available at: www.creditwritedowns.com/2011/03/a-modest-proposal-for-endingdebt-limitgridlock.html.

Wray, R. (2015), Modern Money Theory: A Primer on Macroeconomics for Sovereign Monetary Systems, 2nd edn, New York: Palgrave Macmillan. 